\title{
DESENTRALISASI KEWENANGAN PADA URUSAN PERTAMBANGAN MINERAL DAN BATUBARA DALAM UNDANG-UNDANG NOMOR 3 TAHUN 2020
}

\author{
Oleh \\ Muhammad Salman Al-Farisi \\ Email : Muhsalmanalfarisi02@gmail.com \\ Mahasiswa Pascasarjana Program Magister Ilmu Hukum \\ Universitas Indonesia
}

\begin{abstract}
The revision of Law Number 4 of 2009 to Law Number 3 of 2020 revised 135 articles from the 217 articles contained in Law Number. 4 of 2009, in detail there are 73 articles that have been added, 51 articles have been amended, and 11 articles have been deleted. As many as 19 revised articles relating to the authority of local governments, almost all local government authorities have been withdrawn to the central authority, leaving room for delegation of part of the authority of the Central Government to provincial local governments for the issuance of IPR and SIPB, in this study will present the implications of regional city district governments. no longer have space of authority in coal mineral mining affairs. the authority of the provincial and district / city governments in mining affairs, is a concurrent affair which in its handling involves the central government and regional governments, withdrawing most of the authority and does not involve local governments, of course, has the potential to have negative implications in terms of carrying out mineral and coal mining affairs. for example, it includes profit-sharing funds, corporate social responsibility, local community resistance due to unclear mechanisms for their objection or resistance to the presence of mining in their area, weak issues of supervision and guidance in reducing the level of social and environmental risk, and more importantly reducing the distance between the government and Public.
\end{abstract}

Keywords: Local Government Authority, Mineral and Coal Law.

\section{ABSTRAK}

Revisi Undang-Undang Nomor 4 Tahun 2009 menjadi Undang-Undang Nomor 3 Tahun 2020 merevisi 135 pasal dari 217 pasal yang terdapat pada UU N0. 4 Tahun 2009, yang secara rincih terdapat 73 pasal yang telah ditambahkan, 51 Pasal diubah, dan 11 pasal dihapuskan. Sebanyak 19 pasal yang telah direvisi yang bertalian dengan kewenangan pemerintah daerah hampir seluruh kewenangan pemerintah daerah ditarik menjadi kewenangan pusat menyisakan ruang pendelegasian terhadap sebagian kewenangan Pemerintah Pusat kepada pemerintah daerah provinsi untuk penerbitan IPR dan SIPB, di dalam penelitian ini akan menyajikan implikasi pemerintah daerah kabupaten kota tidak lagi memiliki ruang kewenangan pada urusan pertambangan mineral batubara. kewenangan pemerintah daerah provinsi maupun kabupaten/kota pada urusan pertambangan, merupakan urusan yang bersifat concurrent yang dalam penanganannya melibatkan antara pemerintah pusat dan pemerintah daerah, menarik sebagian besar kewenangan dan tidak melibatkan pemerintah daerah tentu berpotensi berimplikasi negatif dalam hal penyelenggaraan urusan pertambangan mineral dan batubara, misalnya, mencakup dana bagi hasil, tanggung jawab sosial perusahaan, resistensi masyarakat setempat akibat kurang jelasnya mekanisme keberatan atau 
penolakan mereka terhadap kehadiran penambangan di daerahnya, lemahnya isu pengawasan dan pembinaan dalam mengurangi tingkat risiko sosial dan lingkungan, dan lebih penting memangkas jarak antara pemerintah dan masyarakat.

Kata Kunci : Kewenangan Pemerintah daerah, Undang-Undang Mineral dan batubara.

\section{A. PENDAHULUAN}

Amendemen kedua UndangUndang Dasar Negara Republik Indonesia Tahun 1945 (Selanjutnya disebut UUD NRI 1945) memberi kewenangan Otonomi daerah kepada Pemerintah daerah dalam upaya desentralisasi, agar sekiranya daerah mampu menjalankan kewenangan yang seluas-luasnya kecuali urusan-urusan pemerintah yang oleh undang-undang diatur sebagai urusan pemerintah pusat. Namun pasca perubahan Undang-undang Nomor 4 Tahun 2009 menjadi Undang-Undang Nomor 3 Tahun 2020 tentang Mineral dan Batubara, seolah mereduksi kewenangan pemerintah daerah, dengan menghapuskan Pasal-pasal berisi kewenangan pemerintah daerah, kemudian memberikan kepada pemerintah pusat (Maryati Abudullah,2020).

Pada dasarnya UUD NRI 1945 telah mengakomodir konsep desentralisasi dan otonomi daerah seperti yang tertuan pada Pasal 18 Ayat (2) UUD NRI 1945 yang memberikan kewenangan pemerintah provisi maupun pemerintah kabupaten/kota untuk mengatur dan mengurus pemerintahan sesuai dengan asas otonomi dan tugas pembantuan. Menurut Bhenyamin Hoessein Otonomi adalah wewenang menetapkan dan melaksanakan kebijakan dengan prakarsa sendiri (Bhenyamin Hossein, 2009), Lebih jelas Bagir manan menjelaskan hakikat otonomi adalah kemandirian, walaupun suatu bentuk kebebasan melainkan suatu satuan yang merdeka (zelfstadigheid) bukan (onafhankelijkeheid) (Bagir Manan, 2001) hal ini tentu bukan hanya sekedar mengalihkan kewenangan dari pemerintah pusat ke pemerintah daerah, namun tujuan sebenarnya agar masyarakat daerah yang sangat beragam dapat menentukan nasibnya sendiri melalui pemerintah daerah.

Didalam Undang-Undang Nomor 23 Tahun 2014 Tentang Pemerintah daerah (selanjutnya disebut UU Pemda) Pemerintah Daerah kabupaten/kota tidak lagi diberikan kewenangan penerbitan izin pertambangan, menurut Undang-Undang ini hal tersebut hanya menjadi kewenangan pemerintah Provinsi. 
Pengaturan tersebut seolah mereduksi kewenangan pemerintah kabupaten/kota, yang dimana Undang-Undang sebelumnya memiliki porsi kewenangan yang telah jelas ditentukan. Pada saat itu Pemerintah melalui Kementerian Energi dan Sumber Daya Mineral dan Kementerian Dalam Negri mengeluarkan surat edaran mengelanai pengelolaan pertambangan mineral dan batu bara, yang pada intinya mencabut kewenangan Bupati dan Walikota dalam pengelolaan urusan pertambangan mineral dan batubara yang berlandaskan UU Pemda.

Kemudian yang terakhir adalah perubahan Undang-Undang Nomor 4 Tahun 2009 menjadi Undang-Undang Nomor 3 Tahun 2020, justru seolah kembali mereduksi kewenangankewenangan Pemda, dapat dilihat dari Pasal 4 ayat (2) UU Minerba menyebutkan bahwa penguasaan mineral batubara oleh negara diselenggarakan oleh Pemerintah Pusat, yang sebelumnya diselenggarakan oleh pemerintah dan/atau pemerintah daerah, dalam UndangUndang ini juga menghapuskan Pasal 7 dan 8 yang sebelumnya mengatur dengan tegas mengenai kewenangan pemerintah daerah provinsi dan pemerintah kabupaten/kota, selanjutnya memberikan kewenangan yang seluas-luasnya pada pemerintah pusat dalam mengelola pertambangan mineral dan batubara

Tentu saja perubahan pengalihan kewenangan ini tanpa alasan jika melihat pada naskah akademik UU Minerba menjelaskan ;

Pemberian kewenangan kepada pemerintah daerah kabupaten/kota tersebut banyak menimbulkan kendala, hingga akhir tahun 2014 dari sekitar 8000 IUP yang telah dikeluarkan oleh pemerintah daerah kabupaten/kota, lebih dari separuhnya yang bermasalah atau belum clean and clear (CNC). Hal ini menjadi dasar bagi pemerintah pusat untuk berupaya mengatur kembali pengaturan urusan kewenangan bidang mineral dan batubara dengan memperbaiki mekanisme pemberian perizinan tambang mineral dan batubara di seluruh wilayah Indonesia serta pengaturan yang jelas sebagai dasar hukum terhadap proses CNC.

Demikian mengisyaratkan bahwa banyaknya permasalahan ditingkat daerah merupakan persoalan yang harus segera ditindak lanjuti demi terlaksananya pengelolaan tambang yang lebih baik, olehnya itu dengan hadirnya UU Minerba 
yang terbaru diharapkan mampu menyelesaikan permasalahan yang ada di tingkat daerah dengan menarik kewenangan daerah atas pengelolaan tambang dan mengembalikan ke pusat.

Namun tentunya UU Minerba ini mengarah kepada arah sentralisasi, padahal Mahkamah Konstitusi (MK) dalam Putusan MK No. 10/PUU-X/2012 putusan ini menimbang pembagian urusan pemerintah yang bersifat fakultatif haruslah berdasarkan semangat konstitusi yang memberikan otonomi seluas-luasnya kepada pemerintah daerah. Mahkamah Konstitusi menyatakan bahwa daerah memiliki kewenangan dalam menentukan Wilayah Pertambangan (WP), Wilayah Usaha Pertambangan (WUP), serta batas dan luas Wilayah Izin Usaha Pertambangan (WIUP). Maka itu, frasa "setelah berkoordinasi dengan pemerintah daerah" dalam Pasal 6 Ayat (1) huruf e, Pasal 9 ayat (2), Pasal 14 ayat (1) dan ayat (2), Pasal 17 UU No 42009 diubah menjadi "setelah ditentukan oleh pemerintah daerah, Dalam hal ini MK secara tegas menyatakan bahwa pembagian urusan pemerintah dalam konstitusi merupakan otonomi yang seluas-luasnya serta mengakui bahwa pengelolaan sumberdaya mineral dan batu bara berdampak langsung terhadap daerah, namun dengan hadirnya UU Minerba seolah secara bertahap menuju kembali kembali ke arah sentralistik.

Walau dalam UU minerba terbaru mengakomodir kewenangan pemerintah daerah melalui pendelegasian terdapat kewenangan perizinan usaha pertambangan dari pemerintah pusat ke pemerintah daerah, yaitu Izin Pertambangan Rakyat (IPR) dan Surat Izin Penambangan Batuan, tentu hal ini sangat berbeda jika dibandingkan dengan UU Minerba sebelumnya yang secara langsung kewenangan pemberian izin secara atributif,(Seri analisis ICEL, 2020) bukan hanya masalah perizinan komponen penting yang dihilangkan yaitu kewenangan pemerintah daerah terhadap pengawasan pelaksanaan kegiatan usaha pertambangan, semua bentuk pengawasan merupakan kewenangan menteri sesuai Pasal 40 UU Minerba, namun yang menarik adalah tidak adanya ruang pendelegasian kewenangan terhadap pengawasan seperti pada perizinan kepada pemerintah daerah. Tentu hal ini memberikan beban yang besar yang ditanggung kepada pemerintah pusat. Melihat dinamika terhadap kewenangan terkait urusan pertambangan pasca perubahan UU Minerba tentu saja menjadi dikursus yang menarik untuk 
dibahas dalam tesis ini, menakar kembali peran otonomi daerah dan disentralisasi yang telah diamanatkan dalam UUD NRI 1945

\section{B. METODE PENELITIAN}

Bentuk penelitian ini merupakan penelitian yuridis normatif, dimana fokus dari penelitian ini adalah memaparkan teori dan asas-asas hukum mengenai hubungan dan kewenangan pemerintah pusat dan daerah. Selanjutnya berdasarkan teori dan asas tersebut dilakukan analisis mengenai normanorma peraturan perundang-undangan mengenai pengelolaan usaha pertambangan mineral dan batubara untuk memahami mengenai aspek hukum dari hubungan Pemerintah Pusat dan Daerah dalam bidang pertambangan mineral dan batubara.

Tipologi penelitian ini adalah menggunakan tipologi preskriptif, dimana ulasan dan analisis yang dilakukan bertujuan untuk memberikan bukan hanya berupa gambaran namun juga menghasilkan jalan keluar dari identifikasi masalah yang timbul dalam hubungan dan kewenangan Pemerintah Pusat dan Daerah terkait penyelenggaraan pertambangan mineral dan batubara. Dalam penelitian ini untuk memberikan gambaran dan melakukan analisis serta memberikan preskripsi terhadap pokok permasalahan, digunakan data sekunder yang diperoleh melalui studi kepustakaan dan wawancara dengan informan

\section{HASIL PENELITIAN}

Analisis Kewenangan Pemerintah Daerah Dalam Kegiatan Usaha Pertambangan Berdasarkan UndangUndang Nomor 3 Tahun 2020 Dalam Prespektif Hak Menguasai Negara Dan Otonomi Daerah

\section{Kewenangan Pemerintah Daerah} Pada Urusan Pertambangan Mineral Dan Batubara Menurut Undang-Undang Nomor 3 Tahun 2020

Seiring perjalanan waktu dimana sejak 11 tahun penyelenggaraan pemerintahan dibidang pertambangan mineral dan batubara dengan berdasarkan UU No 4 Tahun 2009 dinilai perlu dilakukan revisi. Melihat permasalahan aktual, perkembangan, dan kebutuhan hukum dalam penyelenggaraan pemerintahan dibidan pertambangan mineral dan batubara menjadi alasan perlunya ada revisi terhadap UU No 4 Tahun 2009.

Dalam dinamika pelaksanaan UU No.4 Tahun 2009 telah beberapa kali menjadi objek permohonan untuk diuji konstitusinalitasnya di MK. Tercatat ada 
empat permohonan yang telah dikabulkan oleh MK, baik seluruhnya ataupun sebagian pasal yaitu Pasal 6 Ayat (1) huruf e dan huruf f, Pasal 9 Ayat (2), Pasal 10 huruf b, Pasal 14 Ayat ( 1 ), Pasal 17, Pasal 22 huruf e, dalam Pasal 51 ,Pasal 52 Ayat (1), Pasal 55 Ayat (1), Pasal 60, Pasal 61 ayat (1), Pasal 75. Setidaknya ada 10 pasal yang telah diputuskan oleh MK yang bertentangan dengan UUD NRI 1945 sehingga perlu adanya tindak lanjut untuk merevisi pasalpasal yang telah dinyatakan inkonstitusional oleh MK.

Tumpang tindih penerbitan izin tambang dan non-tambang juga yang menjadi persoalan yang aktual terjadi, misalkan didalam suatu wilayah pertambangan dimungkinkan terdapat berbabagai macam izin yang saling tumpang tindih seperti izin pengelolaan hutan, izin perkebunan dan izin pertambangan. (Ristya Amalia Utami, 2018) Tentu saja ini membuat ketidak pastikan hukum terhadap penyelenggaraannya. Serta sanksi yang dinilai belum efektif terhadap pemegang izin pertambangan yang melakukan pelanggaran administratif maupun pidana, menjadi bagian permasalahan aktual yang terjadi dalam pelaksanaan UU No 4 Tahun 2009.
Dalam UU No. 3 Tahun 2020 setidaknya merevisi 135 pasal dari 217 pasal yang terdapat pada UU N0. 4 Tahun 2009, yang secara rinci terdapat 73 pasal yang telah ditambahkan, 51 Pasal diubah, dan 11 pasal dihapuskan. Sugeng Supartowo ketua komisi VII DPR-RI Periode 2019-2024 mengemukaan pada rapat paripurna DPR-RI, terdapat 15 poin penyempurnaan didalam batang tubuh UU No.4 Tahun 2020.

Terkait kewenangan pemerintah daerah provinsi maupun pemerintah daerah kabupaten kota dibidang pertambangan mengalami perubahan yang signifikan, jika melihat pasal 4 Ayat (2) UU No. Tahun 2020 dalam hal ini hanya menyebutkan penyelenggaraan dibidang pertambangan mineral dan batubara diselenggarakan oleh pemerintah pusat, berbeda dengan Undang-Undang sebelumnya yang tidak hanya menyebutkan pemerintah pusat, namun melibatkan pemerintah Provinsi dan Kabupaten kota. Selain itu kewenangan pemerintah daerah dibatasi dengan dihapuskannya Pasal 7 dan Pasal 8 yang sebelumnya mengatur mengenai kewenangan spesifik pemerintah daerah provinsi dan kabupaten kota dibidang pertambangan mineral dan batubara. Kemudian pada pasal 11 sebelumnya 
mengikutsertakan pemerintah daerah daerah kabupaten/kota tidak lagi dalam hal penyelidikan dan penelitian berwenang dibidang pertambangan. Hal pertambangan mineral dan batubara, ini telah sejalan dengan UU No 24 Tahun namun pasca revisi kewenangan tersebut 2014 yang mengatur mengenai menjadi mutlak menjadi kewenangan pemerintah pusat melalui Menteri Energi dan Sumber daya Mineral (ESDM). Dalam penentuan WUP keterlibatan pemerintah daerah juga dibatasi dengan dihapuskannya pasal 15 yang sebelumnya mengatur mengenai pemberian sebagian kewenangan dalam penentuan WUP oleh pemerintah pusat kepada pemerintah daerah provinsi, walaupun seperti itu dalam hal penentuan WUIP masih melibatkan provinsi.

Begitu pula dengan penentuan WPR yang pada sebelon adanya revisi merupakan kewenangan Pemerintah kabupaten/kota, namun ketentuan yang termuat pada pasal 21 telah dihapuskan pada UU No. 3 Tahun 2020. Setidaknya dalam UU No. 3 Tahun 2020 telah mereduksi kewenangan pemerintah daerah dengan merevisi sebanyak 19 Pasal yang terkait dengan kewenangan pemerintah daerah.Reduksi kewenangan kemudian dialihkan kepada pemerintah pusat, bahkan pengaturan mengenai kewenangan pemerintah daerah kabupaten/kota dibidang pertambangan dihapuskan yang artinya pemerintah kewenangan pertambangan adalah urusan konkuren, yang hanya diberikan kepada pemerintah pusat dan pemerintah daerah provinsi.

Reduksi kewenangan dibidang
pertambangan juga terjadi $\quad$ pada
pemerintah daerah provinsi, Meski
demikian, melalui Pasal 35 ayat (4) UU No 3 Tahun 2020 masih terdapat ruang pendelegasian kewenangan perizinan usaha pertambangan dari Pemerintah Pusat kepada pemerintah daerah provinsi, yaitu untuk penerbitan IPR dan SIPB, namun tentu saja ini kembali lagi kepada Political will pemerintah dalam mengambil kebijakan pendelegasian kewenangan dibidang pertambangan.

Namun di era otonomi daerah yang meletakan pemerintah daerah sebagai struktur negara yang paling dekat dengan masyarakat, kemudian sebagai proses untuk memberikan kepada daerah untuk bisa berkembang sesuai dengan potensi yang dimiliki daerah. Artinya mengurangi peran pemerintah daerah dibidang pertambangan sama halnya tidak memberikan kesempatan kepada daerah untuk mengembangkan potensi sumber 
daya alam, walaupun peran pemerintah pusat dalam konteks negara kesatuan sebagai penanggung jawab utama dalam seluruh penyelenggaraan pemerintah tetapi hal itu tidak dapat mengenyampingkan peran pemerintah daerah sebagai struktur negara yang berada didaerah. Oleh sebabnya otonomi harus bermakna sebagai jalan untuk mengoptimalisasikan seluruh potensi lokal, baik alam, lingkungan, dan kebudayaan. Optimalisasi potensi didaerah bukan sebagai eksploitasi, melainkan sebagai proses yang memungkinkan daerah bisa mengembangkan diri, dan mengubah kehidupan masyarakat daerah menjadi lebih baik (Tim Lapera, 2001)

\section{Prinsip}

\section{Penguasaan}

Negara

Terhadap Sumber Daya Mineral

Dan Batu Bara Dalam Konteks

\section{Otonomi Daerah}

Pada penjelasan umum UU No 3 Tahun 2020 menjelaskan bahwa kandungan Mineral dan Batubara ialah merupakan kekayaan alam yang tidak terbarukan yang proses terbentuknya membutuhkan waktu ribuan bahkan jutaan tahun. Pemanfaatan dan eksploitasi sumber daya alam pemanfaatanya harus berorientasikah kepada kesejahteraan rakyat, sebagaimana didalam ketentuan
Pasal 33 ayat (3) Undang-Undang Dasar Negara Republik Indonesia Tahun 1945 dikuasai oleh negara dan digunakan untuk sebesar-besarnya kemakmuran rakyat. Menurut Tri Hayati sumber daya alam tergolong sebagai public ownership, karena memiliki pengertian milik bersama seluruh bangsa, oleh karena itu agar penggunaanya dapat digunakan untuk sebesar-besarnya kemakmuran rakyat maka perlu dikendalikan oleh negara.( Tri Hayati, 2009) Artinya penguasaan negara terhadap sumber daya alam harus dimaknai sebagai mutlak penguasaan oleh bangsa Indonesia, namun untuk mewujudkan penguasaan tersebut dibutuhkan pengendalian oleh pemerintah sebagai pengendali terhadap kemanfaatannya demi mewujudkan kemakmuran sebesar-besarnya untuk rakyat.

Namun demikian, kesalahan persepsi sebagian pemerintah daerah terhadap penyelenggaraan otonomi daerah secara politis lebih dimaknai sebagai pelimpahan kekuasaan yang absolut dan berorientasi pada kepentingan jangka pendek, sebagaikan daerah berpersepsi khususnya dibidang pertambangan mineral menganggap otonomi daerah membuat daerah memiliki kewenangan penuh dibidang pertambangan, namun 
sesungguhnya jika kita memperhatikan UU No 23 Tahun 2014 kewenangan dibidang pertambangan merupakan kewenangan konkuren, yang artinya kewenangan yang dilakukan secara bersama oleh pemerintah dan pemerintah daerah provinsi. Kesalahan persepsi tersebut berimbas pada pengelolaan pertambangan mineral dan batubara carutmarutnya pengelolaan perizinan, pengawasan dan kerusakan lingkungan dari data tahun 2014 Dari total 10.776 IUP yang keluar, sebanyak 8.000 izin perusahaan tambang dikeluarkan pemerintah kabupaten/kota. Sisanya dikeluarkan oleh Pemerintah provinsi. Permasalahannya dari jumlah itu, sebanyak 4.807 bermasalah atau non clean atau clear. (Muhammad Yazid ,2020)

Revisi UU No 4 Tahun 2009 menjadi UU No. 3 Tahun 2020 mengubah sangat drastis penyelenggaraan pemerintah dan pemerintah daerah dibidang pertambangan mineral dan batubara. Seperti yang telah dibahas pada pembahasan sebelumnya sebanyak 19 pasal yang telah direvisi yang bertalian dengan kewenangan pemerintah daerah hampir seluruh kewenangan pemerintah daerah ditarik menjadi kewenangan pusat menyisihkan ruang pendelegasian terhadap sebagian kewenangan Pemerintah Pusat kepada pemerintah daerah provinsi untuk penerbitan IPR dan SIPB, melalui Pasal 35 ayat (4) UU No 3 Tahun 2020, sedangkan pemerintah kabupaten/kota tidak lagi memiliki kewenangan dibidang pertambangan. Padahal jika melihat pada UU No 4 Tahun 2009 dengan mengusung semangat desentralisasi dan otonomi daerah, kewenangan pemerintah dan pemerintah daerah diatur secara tegas di dalam UU No. 4 Tahun 2009. Pasal 4 ayat (2) UU No. 4 Tahun 2009 menyebutkan bahwa penguasaan mineral dan batubara oleh negara diselenggarakan oleh pemerintah dan/atau pemerintah daerah. Beberapa kewenangan dibidang pertambangan mineral dan batubara yang diberikan kepada pemerintah daerah provinsi dan pemerintah kabupaten kota diantaranya terkait penyelidikan, penelitian dan inventarisasi; pemberian IUP dan IPR; pembinaan, pengawasan serta penyelesaian sengketa.

Walaupun didalam UU No. 23 Tahun 2014 mengatakan urusan pertambangan mineral dan batubara bukanlah menjadi urusan wajib pemerintah daerah, namun bukan berarti tidak mengikut sertakan pemerintah daerah dalam penyelenggaraannya, karena 
tidak dapat kita pungkiri Mineral dan batu bara berdampak langsung terhadap daerah yang menjadi wilayah usaha pertambangan. Terkait hal ini telah disampaikan oleh MK melalui Putusan MK Nomor 10/PUU_X/2020 dalam pertimbangan Hakim MK menjelaskan pengelolaan dan eksploitasi sumber daya alam Mineral dan batubara adalah hal yang berdampak langsung terhadap daerah yang menjadi wilayah usaha pertambangan, baik itu dampak lingkungan yang berpengaruh pada kualitas sumber daya alam, maupun yang mempengaruhi kehidupan masyarakat daerah yang bersangkutan, maupun dampak ekonomi dalam rangka kesejahteraan masyarakat di daerah. Artinya urusan pemerintah dibidang pertambangan mineral dan batubara juga mengikut sertakan pemerintah daerah. Pemberian kewenangan terhadap pemerintah daerah dibidang pertambangan mineral dan batubara diharapkan pertama, dalam penguatan desentralisasi dan otonomi daerah menjadikan rakyat sebagai subjek pembangunan maka dari itu tercipta ruang partisipasi rakyat dan tertampungnya aspirasi rakyat, sehingga dalam pengelolaan sumber daya alam dapat berkelanjutan dan memenuhi semua pemangku kepentingan. (Jeffrey Sayer dan Bruce Campbell,, 2004)

Kedua pengelolaan SDA pada prinsipnya juga bertujuan untuk meningkatkan pendapatan masyarakat di daerah, pemerintah daerah dan negara serta tercipta lapangan pekerjaan untuk masyarakat didaerah. Langkah ini sekaligus juga diarahkan untuk mengurangi potensi konflik di lapangan, memperkuat pengawasan, dan menyederhanakan perizinan dalam skala dan luasan wilayah maupun golongan tertentu. Atas pertimbangan diatas keterlibatan pemerintah daerah dibidang pertambangan seharusnya tidak hanya pada terbatas penerbitan izin IPR dan SIPB namun juga terkait penyelidikan, penelitian dan inventarisasi; pemberian IPR dan SIPB pembinaan, pengawasan serta penyelesaian sengketa. Namun tidak dimaknai memberikan keseluruhan kewenangan, namun hanya sebatas kewenangan bersifat kedaerahan yang memperhatikan kondisi dan potensi daerah.

\section{KESIMUPLAN}

Terkait kewenangan pemerintah daerah provinsi maupun pemerintah daerah kabupaten kota dibidang pertambangan mengalami perubahan yang signifikan, alam UU No. 3 Tahun 2020 
setidaknya merevisi 135 pasal dari 217 pasal yang terdapat pada UU N0. 4 Tahun 2009, yang secara rinci terdapat 73 pasal yang telah ditambahkan, 51 Pasal diubah, dan 11 pasal dihapuskan. Sebanyak 19 pasal yang telah direvisi yang bertalian dengan kewenangan pemerintah daerah hampir seluruh kewenangan pemerintah daerah ditarik menjadi kewenangan pusat menyisihkan ruang pendelegasian terhadap sebagian kewenangan Pemerintah Pusat kepada pemerintah daerah provinsi untuk penerbitan IPR dan SIPB, sedangkan pemerintah kabupaten/kota tidak lagi memiliki kewenangan dibidang pertambangan. Urusan pemerintah dibidang pertambangan mineral dan batubara juga syogunnya mengikut sertakan pemerintah daerah. Pemberian kewenangan terhadap pemerintah daerah dibidang pertambangan mineral dan batubara diharapkan pertama, dalam penguatan desentralisasi dan otonomi daerah menjadikan rakyat sebagai subjek pembangunan maka dari itu tercipta ruang partisipasi rakyat dan tertampungnya aspirasi rakyat, sehingga dalam pengelolaan sumber daya alam dapat berkelanjutan dan memenuhi semua pemangku kepentingan. Kedua pengelolaan SDA pada prinsipnya juga bertujuan untuk meningkatkan pendapatan masyarakat di daerah, pemerintah daerah dan negara serta tercipta lapangan pekerjaan untuk masyarakat didaerah. Langkah ini sekaligus juga diarahkan untuk mengurangi potensi konflik di lapangan, memperkuat pengawasan, dan menyederhanakan perizinan dalam skala dan luasan wilayah maupun golongan tertentu. Memaknai Penguasaan ataupun kewenangan terhadap pertambangan mineral dan batubara dalam rangka caracter state dan dapat diderivasi kepada daerah yang sifatnya kedaerahan (locality state).

\section{DAFTAR PUSTAKA}

Abu Daud Busroh, Ilmu Negara, (Cetakan Pertama, Bumi Aksara, Jakarta, 1990,)

Bagir Manan, Menyongsong Fajar Otonomi Daerah, Pusat Studi Hukum FH UII, Jogjakarta, 2001)

C.F Strong, "Modern Political Constitution : An Introduction to Comparative Study of Their History and Existing Form", (London: Sidgwick and Jackson Limited, 1960)

Hendratno, Edie Toet. Negara Kesatuan, Desentralisasi dan Federalisme, (Yogyakarta: Graha Ilmu, 2009)

Hossein, Bhenyamin. Berbagai Faktor yang Mempengaruhi Besarnya Otonomi Daerah Tingkat II ( Disertasi untuk memperoleh gelar doktor dalam Ilmu Administrasi Negara Pada Universitas Indonesia, Jakarta 1993) 
Indroharto, Usaha memahami UndangUndang tentang Peradilan Tata Usaha Negara, (Pustaka Harapan, 1993, Jakarta).

Mamudji, Sri dkk, Metode Penelitian dan Penulisan Hukum, (Jakarta: Badan Penerbit FHUI, 2005)

Tim Penyusun Kamus-Pusat Pembinaan dan Pengembangan Bahasa, Kamus

Karya Tulis Ilmiah

Seri analisi ICEL, Beberapa Kritik Hukum Terhadap Perubahan Undang-Undang Nomor 4 Tahun 2009 Tentang Mineral dan Batubara,

Wasistiono, Sadu Kajian Hubungan antara Pemerintah Pusat dengan Pemerintah Daerah (Tinjauan dari Sudut Pandang Manajemen Pemerintahan)",Jurnal Adminirtasi Pemerintahan Daerah, Volume I, Edisi Kedua 2004

Peraturan Perundang-undangan

Indonesia. Undang-Undang Dasar Negara Republik Indonesia Tahun 1945.

Indonesia. Undang-Undang tentang Pemerintahan Daerah. UU No. 23 Tahun 2014. LN No. 244 Tahun 2014, TLN No. 5587.

Indonesia. Undang-Undang Tentang Mineral Dan Batubara UU No. 3 Tahun 2020 LN Tahun 2020, TLN No. 6526

Indonesia. Undang-Undang Tentang Mineral Dan Batubara UU No. 4 Tahun 2009 LN Tahun 2009, TLN No. 4952

Putusan, Putusan Mahkamah Konstitusi No. 10 /PUU-X/2012

Internet
Aliansi Masyarakat Adat Nusantara, 5 Masalah UU Minerba Bagi Masyarakat Adat, http://www.aman.or.id/2020/06/5masalah-uu-minerba-bagimasyarakat-adat/

Direktorat Jenderal Mineral dan Batubara, Kementerian ESDM, "Efektivitas Pengawasan dan Penegakan Hukum Sektor Pertambangan Mineral dan Batubara." Bahan presentasi diskusi Pengawasan Pertambangan Mineral dan Batubara yang diselenggarakan Publish What You Pay Indonesia (PWYP), Jakarta, 29 Agustus 2017. Slide 8-9. https://www.slideshare.net/pwypind onesia/efektifitas-pengawasan-danpenegakan-hukum-sektorpertambangan-mineral-danbatubara.

ESDM Desak Gubernur Cabut Ratusan Izin Tambang Bermasalah https://www.cnnindonesia.com/eko nomi/20190109155055-85359627/esdm-desak-gubernurcabut-ratusan-izin-tambangbermasalah. 